\title{
THE KNOWLEDGE OF WRITING IN IRON AGE PALESTINE ${ }^{1}$
}

\author{
Alan Millard
}

\section{Summary}

The Bible presents writing as a normal activity of daily life, but no Hebrew books survive from Iron Age Palestine to attest that. The written documents found there are few and brief in comparison with those from Egypt and Mesopotamia, yet they attest a varied use of writing which, this paper argues, reached beyond the scribal circles of palace and temple. Considered in the light of inscriptions from neighbouring lands, Hebrew epigraphy presents a richer source, lacking only royal monuments. On the basis of that evidence and analogies from other parts of the ancient Near East, a case is made for the possibility of written literature existing in the land from at least the tenth century B.C. onwards.

The Bible implies there was writing among the Israelites from the time of Moses onwards. The verb 'to write' first occurs when Moses wrote an account of the defeat of Amalek (Ex. 17:14), the verb is used of writing God's words, by Moses (Ex. 24:4) and by God himself (Ex. 34:1; Dt. 4:13, etc.). Thereafter it is a normal activity, with the king commanded to write himself a copy of the Law (Dt. 17:18), or the citizen a divorce deed (Dt. 24: 1-3), then there are letters written (2 Sa. 11:14, etc.) and also registers (Nu. 11:26), legal deeds (Je. 32:10), chronicles (1 Ki. 14:19, etc.), prophecies (Je. 36) and advice (Pr. 22:20). That is the testimony of books preserved through generations of religious tradition. How does it stand in the light of epigraphic discoveries in Palestine and adjacent lands?

The recovery of 102 ostraca in the ruins of the citadel at Samaria in 1910 opened a new window on to the administration of a pre-Persian Iron Age state, the onomasticon

\footnotetext{
${ }^{1} \mathrm{~A}$ revised version of a short paper read at the XVth Congress of the International Organisation for the Study of the Old Testament, Cambridge, 16-21 July, 1995.
} 
and the use of writing there. On grounds of stratigraphy and pottery form, those sherds are clearly dated to the eighth century $B C$, and to the earlier part of that century. The simple notes record deliveries of wine or oil to the centre from various places. Sixteen of the twenty-seven place names can be identified with those of Arab villages existing in the past hundred years in the countryside around Samaria (such as Elmatan, 28.3, modern Ammatin, or Sepher, 16a, b. 1, 2, 29.3, modern Saffarin) and seven with place names mentioned in the tribal lists of Manasseh in Numbers 26: 29-34; Joshua 17: 1-13 (e.g., Abiezer,13.1, 2, 28.1, Shemida 3.2, etc., Heleq, 22.1, 27.1). The ostraca name individuals, the fifty-two names falling into common West Semitic types, eleven formed with the divine name $y w$ (e.g., Gaddiyaw, 2.2, etc., Shemaryaw, 13.2, etc.) and six or seven with the divine name $b^{c l}$ (e.g., Abiba'al 2.4, etc., Ba'alme'oni 27.3).

These matters have been fully discussed and need no more attention here. ${ }^{2}$ Our interest lies in these ostraca as examples of an ephemeral kind of writing, administrative notes which were not intended for consultation long after they were written, but have survived simply because they were thrown away and used as make-up for a later floor. It is not hard to visualize their creation. Loaded donkeys or wagons ( $c f$. Am. 2:13) arrived in the citadel to deliver the produce to the official store. At the doorway a clerk counted each consignment and scribbled a note of it on a potsherd. After his morning's or his day's work, he collected the sherds in a basket and took them to the administrative office where, we can assume, the information was sorted, consolidated and entered in a more formal account, probably on a papyrus scroll. The ostraca were then jettisoned. This assumption is based on practices attested where more extensive documentation survives, in Babylonia and Assyria (especially under the Third Dynasty of Ur at the end of the third millennium BC), and in Egypt.

2A. Lemaire, Inscriptions hébräiques. Les ostraca (Paris: Cerf, 1977) 23-81; J. Renz, W. Röllig, Handbuch der althebräischen Epigraphik (Darmstadt: Wissenschaftliche Buchgesellschaft, 1995) 79-109. 
The nature of the Samaria ostraca implies they were an ordinary part of the routine activity in the citadel, neither the work of a specialist scribe in a private office, nor a novelty. The clerk noting the deliveries would probably be visible to the drivers of the wagons and donkeys, the porters and the storemen. Egyptian tomb models of the second millennium BC show a scribe sitting in the granary writing as the porters bring in the sacks of grain. At Samaria, a number of people would have been aware, therefore, of the man making marks on potsherds, aware that what he was doing could affect their wealth, or their master's, considerably. There is no information about the reason for those deliveries to Samaria. If they were taxes, however, a system of assessment would be necessary, and so surveyors and scribes may have measured fields and estimated crop yields.

Again, Egypt illustrates the process. Tomb scenes depict scribes at work in the fields in that way. ${ }^{3}$ So scribes would have entered the horizon of farmers and their labourers who would recognize that the task those strangers performed, even if unintelligible to them, had a direct impact on their lives. Ancient Israel was much smaller than Egypt and its administration may have been less highly organised, yet the Samaria ostraca, and others, prove that there was a degree of control which would have required clerical attention of a similar sort.

There were more written documents at Samaria. Apart from the fragment of a stone stele with the letters ' $\underline{\underline{s}} r$ and a scattering of other ostraca, there were writings on papyrus. They have perished, but the fifty or more clay bullae which secured them survived, albeit in fragments, and bear seal impressions on one side, some with inscriptions, and papyrus fibre marks on the other side. 4 Given the evidence for writing among Aramean and Transjordanian kingdoms displayed by

\footnotetext{
${ }^{3}$ For examples from the fifteenth century BC, see N.M. Davies, A.H. Gardiner, Ancient Egyptian Paintings (Chicago: Chicago UP, 1936) pls. 50, 67.

${ }^{4}$ J.W. Crowfoot, G.W. Crowfoot, K.M. Kenyon, et al., Samaria-Sebaste III. The Objects from Samaria (London: Palestine Exploration Fund, 1957) 2, 85, 88,89 nos. $29-41$.
} 
various stone monuments from the ninth and eighth centuries BC (e.g., Tell Fekheriye Statue, Zakkur Stele, Moabite Stone and Kerak Inscription), writing is to be expected in a royal town like Samaria through those years. Outside the royal centre, there are traces of writing at a few other sites in the northern area, in the form of names and titles scratched on pots in Hebrew, Aramaic and Phoenician, such as those from houses in Hazor (e.g., 'Pekah's: perfumed wine' lpqh smdr), or those found during a surface survey in the 'Manasseh' region. 5

In the south of the country, Jerusalem has yielded meagre monumental inscriptions on stone: three fragments of inscribed stone plaques from excavations since 1967,6 and the most famous ancient Hebrew inscription, the one from the Siloam Tunnel, which palaeography clearly places about 700 BC. There are a some thirty ostraca and graffiti from various parts of the town, some from sealed, stratified deposits of the seventh or early sixth centuries. Jerusalem has also yielded clay bullae, witnesses to the one-time presence of papyrus documents. ${ }^{7}$ Outside the city, some of the tombs in Silwan had notices of ownership cut in the rock face.

Across the territory of Judah very many more inscriptions have come to light from the Iron Age than in the north, most of them belonging to the seventh and early sixth centuries BC. Yet some date from earlier times. Leaving aside those from the twelfth and eleventh centuries, the arrowheads of El Khadr, a few graffiti and the Isbet Sarta ostracon, which Benjamin Sass has treated in detail, 8 the new Handbuch der althebräischen Epigraphik of J. Renz and W. Röllig assigns four texts to the tenth century, three of them are brief notes on pots (one of those may be rather later, according of the form of the vessel), the other one is the Gezer Calendar. Although the

5Hazor: Renz and Röllig, Handbuch, 124-27; Manasseh: A. Lemaire, 'Notes d'épigraphie nord-ouest sémitique', Semitica 32 (1982) 15-20; Renz and Röllig, Handbuch, 199.

6Renz and Röllig, Handbuch, 189, 190, 266.

7Y. Shiloh, 'A Group of Hebrew Bullae from the City of David', IEJ 36 (1986) 16-38.

8B. Sass, The Genesis of the Alphabet in the Second Millennium B.C. (Ägypten und Altes Testament 13; Wiesbaden: Harrassowitz, 1988). 
dating of the Calendar relies heavily on palaeography and orthography, no effective argument has been mounted against it. Whether the Calendar was a school exercise or a peasant farmer's attempt to note his yearly tasks, it reveals a use of writing beyond the basically administrative.

The same is true for the Kuntillet 'Ajrud graffiti, dated in the ninth century. There the widely discussed invocations to Yahweh and his Asherah,9 written alongside alphabets and other texts on stone and pottery vessels and on the wall plaster, exhibit the same flexibility in the use of writing in Hebrew and Phoenician. Beside those, and continuing into the eighth century, are administrative ostraca from Arad and, late in that century, appears the earliest letter preserved, Arad Ostracon 40.10 Accountancy texts form the bulk of the seventh century ostraca, with a number of well-known letters from Lachish and Arad, graffiti of various kinds and many inscribed seals and weights. There was no purpose in engraving an owner's name on a tiny stone seal unless it was intended to be recognised at some stage and since the inscribed Hebrew seals greatly outnumber those from every other area using a West Semitic language, a stronger impetus, possibly bureaucratic, to have one's name on a seal evidently existed there.11

The distribution of epigraphic finds in Iron Age Palestine demonstrates their wide spread. The collection of Renz and Röllig contains some 485 texts from 47 sites within the land, but does not include the hundreds of seals, seal impressions and weights. These documents are by no means confined to the capitals and are found at very many more than the seven Judean sites of the eighth and seventh centuries

${ }^{9}$ See J.A. Emerton, 'New Light on Israelite Religion: The Implications of the Inscriptions from Kuntillet 'Ajrud', ZAW 94 (1982) 2-20; R.S. Hess, 'Yahweh and His Asherah? Religious Pluralism in the Old Testament World' in A.D. Clarke, B.W. Winter (eds.), One God, One Lord (2nd ed.; Carlisle: Paternoster, 1992) 13-42; Renz and Röllig, Handbuch, 47-64.

10A. Lemaire, Inscriptions, 207-09; Renz and Röllig, Handbuch, Arad (8): 40. ${ }^{11}$ See P. Bordreuil, 'Sceaux inscrits du Pays du Levant', Dictionnaire de la Bible, Supplément 12 (Paris: Letouzey et Ané, 1992) 86-212; cf. A.R. Millard, 'The Uses of the Early Alphabets', in Cl. Baurain, C, Bonnet, V. Krings (eds.), Phoinikeia Grammata. Lire et écrire en Méditerranée (Namur: Société des études classiques, 1991) 101-14, especially 107-09. 
which D.W. Jamieson-Drake counted as 'containing direct evidence of writing. ${ }^{12}$ The fort at Arad evidently had clerks in action from the eighth to the sixth centuries, recording or receiving military and other messages as well as daily receipts and issues of supplies. The potsherds bearing single names, two of which the Bible associates with priestly families, Meremoth and Pashhur, may have served as ration tickets or as some other form of identification. ${ }^{13}$ The commandant of Arad near the end of the seventh century BC, Eliashib, had at least three seals engraved with his name. Clearly there was a good deal of writing going on there and, consequently, a wider knowledge of it. Beyond the official establishments, pottery vessels carrying notes of their content or their owners' names, seals and graffiti occur at disparate sites, large and small, and in tombs. The messages scratched on tomb walls in the Judaean hills show a readiness to honour the dead on the part of some mourners who proved their ability to write more than their names or documents of accountancy. ${ }^{14}$

The variety and distribution of these finds speaks against the recent assertion that scribes producing literary works 'were in large measure insulated from the majority of the population; physically (they lived in cities), economically (they were supported by the taxpayer) and culturally' and that '[i]t is in the palace or temple... that the written scrolls will have been deposited.' 15 The evidence from Iron Age Palestine tells against that position, the evidence from the lands to the north and east, where cuneiform was current, contradicts it. Although the scripts and administrations differed, there was no iron curtain between the ancient societies or states, rather there was

12D.W. Jamieson-Drake, Scribes and Schools in Monarchic Judah (JSOTS 109; Sheffield: Sheffield Academic Press, 1991) 147-48. The failures to use the available material evidence in this book, whatever may be said about the theory, render it misleading; see the critical review by A. Lemaire, JAOS 112 (1992) 707-08 and my notice in SOTS Book List 1992, 34.

13Lemaire [n.1], 211-15; Renz and Röllig [n.1], 160-65.

14Renz and Röllig Handbuch, 199-202 (Khirbet el-Kom), 242-50 (Khirbet Beit Lei). Compare also the memorial painted on a stalactite in a cave near Engedi, ibid., 173-75.

15P.R. Davies, In Search of 'Ancient Israel' (JSOTS 148; Sheffield: Sheffield Academic Press, 1992) 107-08, 111. 
considerable interchange across the Fertile Crescent from the earliest times and, in the Iron Age, from the ninth century BC onwards, as Assyria expanded. Assyria received strong influences from the west as a result of her military activities and policy of deportation. Letters of the Aramaic alphabet were already in use to guide craftsmen building the palace of Shalmaneser III (858-824 BC) at Nimrud,16 and, conversely, as seen in the cuneiform texts from Samaria and Gezer, 17 Assyrian rule brought the cuneiform script and writing habits back to the Levant from that time on. It is, accordingly, acceptable to adduce scribal practices well-attested in one area to help reconstruct the situation in another where the evidence is poorer. Far from it being the case that ' $[\mathrm{w}]$ here literary archives have been unearthed in the ancient near east they have been either at temple sites... or royal archives, ${ }^{\prime} 18$ archaeologists have unearthed archives of cuneiform tablets comprising legal, business and literary texts in private houses of the eighteenth century BC at Ur and Nippur, of the seventh century BC at Assur and, in the Levant, of the thirteenth century BC at Ugarit, to take only the most obvious and well-publicized examples. ${ }^{19}$ At Ur two houses in every five in the residential areas of the eighteenth century BC excavated by Sir Leonard Woolley contained cuneiform tablets, ${ }^{20}$ and the proportion was similar in seventh century Assur. Even if these 'domestic' archives belonged to dependents of a temple or palace, they were situated in houses standing among the dwellings of other

\footnotetext{
16A.R. Millard, 'The Graffiti on the Glazed Bricks from Nimrud', Iraq 55 (1993) 35-36.
}

17See B. Becking, The Fall of Samaria (Leiden: Brill, 1992) 112-18; note also the Neo-Assyrian fragment from Tell Keisan, M. Sigrist, 'Une tablette cunéiforme de Tell Keisan', IEJ 32 (1982) 32-35.

18Davies, In Search of 'Ancient Israel, 110.

${ }^{19}$ For Assur see O. Pedersén, Archives and Libraries in the City of Assur; II (Uppsala: Almqvist and Wiksell, 1986); for Ugarit see P. Bordreuil, D. Pardee, La trouvaille épigraphique de l'Ougarit, 1. Concordance (Paris: Editions Recherche sur les Civilisations, 1989).

20Sir Leonard Woolley, Sir Max Mallowan, ed. T.C. Mitchell, Ur Excavations VII. The Old Babylonian Period (London: The British Museum, 1976) 12-29, 95-168 passim; D. Charpin, Le Clergé d'Ur au siècle d'Hammurabi (XIXe-XVIIIe siècles av. J.-C.) (Geneva: Droz, 1986). 
citizens and no different from them, so the neighbours can hardly have been unaware of the activities followed in them. Some of the owners had religious roles and possessed literary texts in that connection, others were merchants who kept their bills and letters. Messengers carrying letters travelled frequently and far, spreading written documents in another way, as the Mari archive shows for the Middle Bronze Age, Ugarit and the El Amarna Letters for the Late Bronze Age and the royal correspondence from Nineveh for the Early Iron Age. Nothing suggests writing was an esoteric art practiced in secret, rather Babylonian, Assyrian and other kings proudly erected monuments covered with tiny cuneiform script for public view in their own cities, in conquered places and at the roadside. Few may have had the skill to read them, yet many would see and know there was writing on them which might tell them a story and, as Hammurabi advises in the Epilogue to his famous Laws, could invite a scribe to read them aloud if they desired.

The question, 'Why are there no royal monuments from Israel and Judah?' has received various answers. The most satisfactory reply is still to hold archaeological accident responsible. The capitals of Samaria and Jerusalem were subject to repeated destruction and rebuilding, so any stone stelae were liable for re-use as building blocks. That was the fate of the 'Pilate Stone' erected in the first century, but found built into a later staircase in the theatre at Caesarea. ${ }^{21}$ It is salutary to remember that not one monumental inscription of a king of a more recent era, the greatest builder the land has ever seen, king Herod, has been found within his realm, despite the impressive visible remains of his work, nor has any survived from the Hasmonean rulers. The Aramean stelae are sparsely distributed, with not one from the kingdom of Damascus, yet they, with the Moabite Stone and others from Transjordan, prove that rulers of small states of the Levant in the Iron Age could erect inscribed monuments.

The Moabite Stone is a narrative text and leads to the question of writing literature. With writing in use in Iron Age

${ }^{21}$ A. Frova, 'L'Iscrizione de Ponzio Pilato a Cesarea', Istituto Lombardo, Rendiconti. Classe di Lettere e Scienze morale e storiche, 95 (1961) 419-34. 
Palestine for the business of daily life and for dedications and funerary inscriptions, it would be very strange were it not also used for preserving literature. Only in the first stages of writing in Sumer was script limited to administrative purposes and it soon expanded into religious and magical compositions and other sorts of literature. In Iron Age Palestine, where the technology of writing in various scripts had been known for a long time and the alphabet inherited from the Late Bronze Age inhabitants, there is no reason to suppose that a newly established state would have to experience each stage of writing's development before it could use a script, or that literary works were not written on papyrus or leather scrolls throughout the period. The scrolls would, of course, disintegrate if buried in a town or village; the unusual dehydration in the Wadi Murabba'at has preserved one papyrus fragment from about $600 \mathrm{BC}$, used first for a letter then for a ration list. ${ }^{22}$ Although the scrolls have disappeared, there are adequate traces to assure us that there was written literature in Iron Age Palestine. Mesha's narrative is very similar to passages in the book of Judges, as long observed, and is difficult to accept as a unique composition, indeed, it may be based upon a fuller report of the king's reign. At about the same time as the Moabite Stone was engraved in Jordan, another stele was engraved in Aramaic and erected in Dan - the palaeography points to a date late in the ninth century BC - that also reports a military campaign, mentioning the House of David' which is at least as likely to refer to the ruling dynasty of Judah as to be a place-name. ${ }^{23}$ Evidently scribes were composing literary narratives to celebrate royal achievements. Further, that was the period when someone in the Jordan Valley copied a story about a prophet, Balaam, on to the plastered wall of a room at Tell Deir 'Alla, carefully writing it to reproduce the appearance of a column in a scroll. (The carbon 14 test applied to vegetation débris on the floor of the room has shown a date within the range $880-770 \mathrm{BC}$, with the greatest

22Renz and Röllig, Handbuch, 283-87.

23Primary publications; A. Biran, J. Naveh, 'An Aramaic Stele Fragment from Tel Dan', IEJ 43 (1993) 81-98; "The Tel Dan Inscription: A New Fragment', IEJ 45 (1995) 1-18. 
probability about $800 \mathrm{BC} .{ }^{24}$ ) The Balaam text is not a royal narrative but a religious one. All three cases come from court or priestly circles. The silver amulets from the Ketef Hinnom tomb opposite the south wall of Jerusalem may be priestly creations, too. ${ }^{25}$ There the sacred words of the 'Priestly Benediction', now found in Num 6: 24-26, were inscribed on the tiny silver leaves and hidden as the metal was rolled up, never intended to be read; it was the knowledge that the text was written that was important for the wearer. Beyond the walls of the dominant institutions, traces of literary writing appear at two sites late in the seventh century BC. At Arad Ostracon 88, beginning 'ănî mālaktî, 'I became king', may be a copy of a story or a free composition. At Horvat 'Uza in the eastern Negev, another potsherd bears thirteen lines in ink. Poor preservation precludes a complete rendering, but enough remains to show this is a literary fragment, or part of a letter with literary pretensions, cursing one who fails to carry out a certain task. ${ }^{26}$ It is legitimate to suppose that a scribe trained to write administrative documents and letters would have been capable of writing or copying a literary text, for the estimation of space and the layout would not have differed from those of a longer set of accounts or letter. Although the only examples to survive in a West Semitic alphabetic script are the Elephantine Papyri belonging to the Persian period, where most notably the Story of Ahiqar was written over a long accountancy document, their evidence is adequate and Egyptian practice indicates that they continued a long-known scribal tradition.

The material remains from Iron Age Palestine and from her neighbours using the same simple alphabetic script, as well as the comparisons with Mesopotamia and Egypt point to a

${ }^{24}$ M.M. Ibrahim, G. van der Kooij, 'The Archaeology of Deir 'Alla Phase IX' in J. Hoftijzer, G. van der Kooij (eds.), The Balaam Text from Deir 'Alla Re-evaluated (Leiden: Brill, 1991) 16-29, especially 28, 29.

${ }^{25}$ G. Barkay, 'The Priestly Benediction on Silver Plaques from Ketef Hinnom in Jerusalem',Tel Aviv 19 (1992) 139-92; Renz and Röllig [n. 1] 44756.

26I. Beit-Arieh, 'A Literary Ostracon from Horvat 'Uza', Tel Aviv 20 (1993) 55-63, with Appendix by F. M. Cross, 'A Suggested Reading of the Horvat 'Uza Ostracon', 64, 65. 
widespread knowledge of the existence of writing and its powers, both for business and for culture, throughout the Iron Age, and to the presence of some people who could read and write within reach of most towns and villages in the area. T.L. Thompson's assertion that 'we cannot seek an origin of literature in Palestine prior to the eighth, or perhaps even better the seventh century'27 does not rest upon the facts of written or archaeological sources but upon hypothetical considerations. The paucity of epigraphic remains from the tenth and ninth centuries in Palestine is part of a phenomenon common across the Fertile Crescent and is explicable as an archaeological accident; it is not an indication of a lack of writing. ${ }^{28}$ As already stated, Palestine would be unique if there was no writing of literary texts there from early in the first millennium $B C$ onwards, beside the writing of administrative, legal and diplomatic documents.

27T.L. Thompson, Early History of the Israelite People From the Written and Archaeological Sources (Studies in the History of the Ancient Near East 4; Leiden: Brill, 1992) 391.

${ }^{28}$ Millard, 'The Uses of the Early Alphabets', 104-10. 